\title{
Differentiation Response of Acute Promyelocytic Leukemia Cells and PML/RAR $\alpha$ Leukemogenic Activity Studies by Real-Time RT-PCR
}

\author{
Sara Caprodossi, ${ }^{1,2}$ Marika Pedinotti, ${ }^{1}$ Consuelo Amantini, ${ }^{3}$ Giorgio Santoni, ${ }^{3}$ \\ Saverio Minucci, ${ }^{2,4}$ Pier Giuseppe Pelicci, ${ }^{2,5}$ and Mirco Fanelli, ${ }^{1, *}$
}

\begin{abstract}
Acute promyelocytic leukemia (APL) is a human cancer generated by a chromosomal translocation $\mathrm{t}(15 ; 17)$ involving the promyelocytic leukemia (PML) and retinoic acid receptor alpha (RAR $\alpha)$ genes. The $\mathrm{PML} / \mathrm{RAR} \alpha$ oncoprotein expressing blasts show two of the most important biological features of neoplastic progression: block of differentiation, at the promyelocytic state, and increased survival. Although PML/ RAR $\alpha$ interferes with the normal maturation of myeloid precursors to granulocytes, pharmacological doses of retinoic acid are sufficient to restore the differentiation processes.

We designed an assay based on the Real-Time reverse transcriptase polymerase chain reaction (RT-PCR) to experimentally follow the differentiation response of leukemic cells even after short-time differentiating treatments. Amplifying CD11b, CD11c, and CD14 mRNAs, as specific markers of differentiation, by the real-time RT-PCR assay we could detect both retinoic acid (RA) and vitamin $\mathrm{D}_{3}$ and human transforming growth factor $\beta_{1}\left(\mathrm{VitD}_{3} / \mathrm{TGF}_{1}\right)$ induced cellular maturation more precociously than the canonical flowcytofluorimetric assay. Moreover, by amplifying CD14 mRNA it was possible to monitor the ability of $\mathrm{PML} / \mathrm{RAR} \alpha$ oncoprotein to block $\mathrm{VitD}_{3} / \mathrm{TGF} \beta_{1}$ induced differentiation in U937-PR9 promonocytic inducible model systems.

The proposed real-time quantitative RT-PCR approach is a reproducible and highly sensitive assay and can be considered a valid method to study both cellular maturation state and differentiation response.

Index Entries: PML/RAR $\alpha$; APL; real-time; quantitative RT-PCR; differentiation.
\end{abstract}

\section{Introduction}

Human acute promyelocytic leukemia (APL) is most frequently characterized $(>90 \%)$ by a chromosomal translocation $\mathrm{t}(15 ; 17)(\mathrm{q} 22 ; \mathrm{q} 21)$ that fuses promyelocytic leukemia (PML) and retinoic acid receptor alpha $(\mathrm{RAR} \alpha)$ genes in the resulting PML/RAR $\alpha$ oncogene (1-5). One of the most interesting features of PML/RAR $\alpha$ expressing cells is the sensitivity at pharmacological doses of retinoic acid (RA) treatments (6). In fact, high doses of RA $(1 \mu M)$ are sufficient to restore the differentiation processes allowing blasts to terminal maturation. Generally, the cellular response to several differentiative agents can be monitored cytofluorimetrically by following the modulation of specific surface antigen expression. Considering the APL model, differentiation response of the blasts can be followed by evaluating the increased expression of specific CD11b and CD11c surface antigens after 4-5 d of RA treatment (7-9).

The crucial biological property of PML/RAR $\alpha$ fusion protein to block the differentiation process at the promyelocytic maturation stage of the blasts

*Author to whom all correspondence and reprint requests should be addressed. ${ }^{1}$ Center of Biotechnology, University of Urbino, Via Campanella 1, 61032 Fano, Italy. E-mail: mirco.fanelli@uniurb.it. ²Department of Experimental Oncology, European Institute of Oncology,

20141 Milan, Italy. ${ }^{3}$ Department of Pharmacological Sciences and Exp. Medicine, University of Camerino, Italy. ${ }^{4}$ Department of Biomolecular Sciences and Biotechnologies, Faculty of Biological Sciences, University of Milan, 20132, Italy. ${ }^{5}$ FIRC Institute for Molecular Oncology (IFOM), 20139 Milan, Italy.

Molecular Biotechnology @ 2005 Humana Press Inc. All rights of any nature whatsoever reserved. 1073-6085/2005/30:3/231-238/\$30.00 
has been studied following the CD14 antigen expression in U937 cells induced to differentiate by vitamin $\mathrm{D}_{3}\left(\mathrm{VitD}_{3}\right)$ and human transforming growth factor $\beta_{1}\left(\mathrm{TGF}_{1}\right)$ (7).

Real-time reverse transcriptase polymerase chain reaction (RT-PCR) assay offers the same sensitivity of canonical amplification assay with the possibility to quantify the amount of amplified PCR product during the exponential phase of the reaction. The detection of amplified products can be carried out by measuring the fluorescent signal produced by the binding of SYBR Green dye to double-stranded DNA (dsDNA) (10).

Here we propose an alternative experimental strategy to follow the RA-induced cellular differentiation of the APL blasts based on the RealTime quantitative RT-PCR assay. Compared to fluorescence-activated cell sorter (FACS) procedure, the RT-PCR method allowed us to monitor either the maturation response of the blasts at short times of RA-treatment and the leukemogenic properties of the PML/RAR $\alpha$ oncofusion protein.

\section{Materials and Methods}

\subsection{Cell Lines}

Human APL cell line NB4 was obtained from Dr. M. Lanotte (INSERM, Paris, France) (11). U937-MT and U937-PR9 promonocytic inducible cellular clones were previously described (7). All cell lines were cultured in RPMI 1640 medium supplemented with $10 \%$ fetal bovine serum (FBS), $1 \%$ penicillin-streptomycin, $1 \%$ glutamine. U937-PR9 cells (U937-MT as control) were induced to express PML/RAR $\alpha$ protein by addition of $100 \mu \mathrm{M} \mathrm{ZnSO}_{4}$ for $12 \mathrm{~h}$. Cell proliferation was evaluated by direct cell counting (trypan blue exclusion method). Pharmacological treatments were performed at the density of $3 \times 10^{5}$ cells/ $\mathrm{mL}$. PML/RAR $\alpha$ expression was monitored by western blotting analysis using an anti-RAR $\alpha$ antibody (St. Cruz) (12).

\subsection{Cell Differentiation}

NB4 cellular differentiation was induced by $1 \mu M$ RA treatment (Sigma). Differentiation of U937-MT and U937-PR9 cells was induced with $250 \mathrm{ng} / \mathrm{mL}$ 1,25 dihydroxy $\mathrm{VitD}_{3}$ (Hoffman-La Roche) combined with $1 \mathrm{ng} / \mathrm{mL}$ TGF $\beta_{1}$ (ICN Biomedicals).
Cells were counted, collected, and prepared for RNA isolation or analyzed for expression of cell surface differentiation markers.

\subsection{RNA Extraction}

Total RNA isolation was performed by using RNeasy Mini Kit (Qiagen) starting from $5 \times 10^{6}$ cells previously washed in phosphate-buffered saline (PBS). Cellular homogenization was performed by QIAshredder spin columns (Qiagen).

RNase-free water and RNase-free experimental material were obtained by treatment with $0.05 \%$ diethylpyrocarbonate (DEPC).

RNA concentration was calculated by specthrophotometric analysis and the integrity was checked by agarose gel electrophoresis.

\subsection{One-Step Real-Time RT-PCR}

mRNA relative quantification of different samples was carried out by One-Step Real-Time RT-PCR on an ABI Prism7000 Sequence Detection System (PE Applied Biosystem). Fifty nono-grams of total RNA of each sample were added to a $25 \mu \mathrm{L}$ total volume reaction containing $12.5 \mu \mathrm{L}$ Hot-Rescue Real-Time master mix (Diatheva), $0.025 \mathrm{U} / \mu \mathrm{L}$ Hot-Rescue DNA Polymerase (Diatheva), $0.25 \mathrm{U} / \mu \mathrm{L}$ M-MuLV Reverse Transcriptase (Diatheva), 0.4 U/ $\mathrm{LL}$ RNasin RNase Inhibitor (Promega), $300 \mathrm{n} M$ sense and anti-sense primer.

Thermal cycling parameters for One Step RTPCR were: 1 cycle at $48^{\circ} \mathrm{C}$ for $30 \mathrm{~min}$ (RNA reverse-transcription); 1 cycle at $95^{\circ} \mathrm{C}$ for $15 \mathrm{~min}$ (DNA Polymerase activation); 40 cycles at $95^{\circ} \mathrm{C}$ for $15 \mathrm{~s}$ and $60^{\circ} \mathrm{C}$ for $1 \mathrm{~min}$ (PCR).

\subsection{Primers}

The primers were designed using Primer Express software (Applied Biosystem) to amplify 100-150 bp cDNA target sequences and with an optimal annealing temperature of $60^{\circ} \mathrm{C}$. The primers were purchased from MWG Biotech and reported in Table 1.

\subsection{RT-PCR Data Analysis}

The relative amount of target mRNA was calculated by the $2^{-\mathrm{DDCt}}$ method (13). Each sample was analysed using glyceraldehyde-3-phosphate dehydrogenase (GAPDH) as endogenous refer- 
Table 1

Primers Used in Real-Time RT-PCR

\begin{tabular}{|c|c|c|c|}
\hline Gene & & Primers & Amplicon size (bp) \\
\hline GAPDH & $\begin{array}{l}\text { sense: } \\
\text { anti-sense: }\end{array}$ & $\begin{array}{l}\text { 5'-GCAAATTCCATGGCACCGT-3' } \\
: \text { 5'-TCGCCCCACTTGATTTTGG-3' }\end{array}$ & 106 \\
\hline CD11b & $\begin{array}{l}\text { sense: } \\
\text { anti-sense: }\end{array}$ & $\begin{array}{l}\text { 5'-CCTGGTGTTCTTGGTGCCC-3' } \\
\text { 5'-TCCTTGGTGTGGCACGTACTC-3' }\end{array}$ & 102 \\
\hline CD11c & $\begin{array}{l}\text { sense : } \\
\text { anti-sense: }\end{array}$ & $\begin{array}{l}\text { 5'-CCGATTGTTCCATGCCTCAT-3' } \\
: \text { 5'-AACCCCAATTGCATAGCGG-3' }\end{array}$ & 154 \\
\hline CD14 & $\begin{array}{l}\text { sense: } \\
\text { anti-sense: }\end{array}$ & $\begin{array}{l}\text { 5'-AAAGGACTGCCAGCCAAGCT-3' } \\
\text { 5'-GATTCCCGTCCAGTGTCAGGT-3' }\end{array}$ & 112 \\
\hline
\end{tabular}

ence gene for mRNA normalization. Variations in mRNA expression levels of different samples were valuated as fold-induction compared with untreated sample.

\subsection{FACS Analysis}

The expression of CD11b, CD11c, and CD14 differentiation markers was valuated by FACS analysis.

Five $\times 10^{5}$ cells were harvested, washed in $1 \mathrm{~mL}$ of PBS/1\%BSA solution, and incubated 30 min on ice with the specific mouse anti-human antibodies: anti-CD11b (clone Leu TM-15; Becton Dickinson), anti-CD11c (clone KB90; Dako), and anti-CD14 hybridoma supernatant (clone UCHM1; European Institute of Oncology).

Cells were washed once in $1 \mathrm{~mL}$ of PBS/ $1 \%$ BSA solution, incubated 30 min with the FITC-conjugated goat anti-mouse antibody (GAM; Sigma) at room temperature (light protected) and washed three times. Cellular pellet was fixed by incubation for $20 \mathrm{~min}$ in $0.5 \mathrm{~mL}$ of PBS and $0.5 \mathrm{~mL}$ of $2 \%$ formaldehyde, washed, and resuspended in $0.5 \mathrm{~mL}$ of PBS. Cells were then analyzed for relative fluorescence intensity. The percentage of positive cells and the mean fluorescence intensity determined over 20,000 events, were analyzed on a FACScan cytofluorimeter (Becton Dickinson).

\section{Results and Discussion}

\subsection{RA-Induced Differentiation by Real- Time Quantitative RT-PCR in NB4 Cells}

Human APL NB4 cell line was used as leukemic model to investigate the possibility to use the quantitative RT-PCR assay for cell differentiation studies. Promyelocytic NB4 blasts are characterized by the constitutive expression of PML/RAR $\alpha$ fusion protein (9). In order to evaluate the most precocious differentiation response we treated NB4 cells with high doses $(1 \mu M)$ of RA for different lengths of times $(8,12$, and $24 \mathrm{~h})$. To simplify the procedure, we designed the RT-PCR profile to perform the RNA reverse-transcription and cDNA amplification reactions in the same reaction mixture. Fifty nanograms of the isolated total RNA were subjected to One-Step RT-PCR assay to amplify the genes of interest as described in "methods" section.

We monitored the mRNA expression levels of CD11b and CD11c as specific markers of granulocytic differentiation. Moreover, we amplified CD14 as not specific control and GAPDH as internal control to normalize the samples for the amount of RNA added to each RT-PCR reaction. As previously described the expression of $\mathrm{CD} 11 \mathrm{~b}$ and CD11c surface antigens is considerably induced in response to long RA treatment (4-5 d) $(7,9)$. In our conditions, the RT-PCR assay was able to monitor the increased amount of both CD11b and CD11c mRNA expression levels induced by RA (Fig. 1; Table 2, three independent experiments). The increased expression of CD11b and CD11c mRNA can be already monitored after $8 \mathrm{~h}$ of RA treatment. Moreover, we could not detect any induction of CD14 mRNA expression supporting the specific NB4 cellular response to RA treatment (data not shown). The SYBR Green dye, present in the reaction mixture, is unable to discriminate specific PCR product from an unspe- 


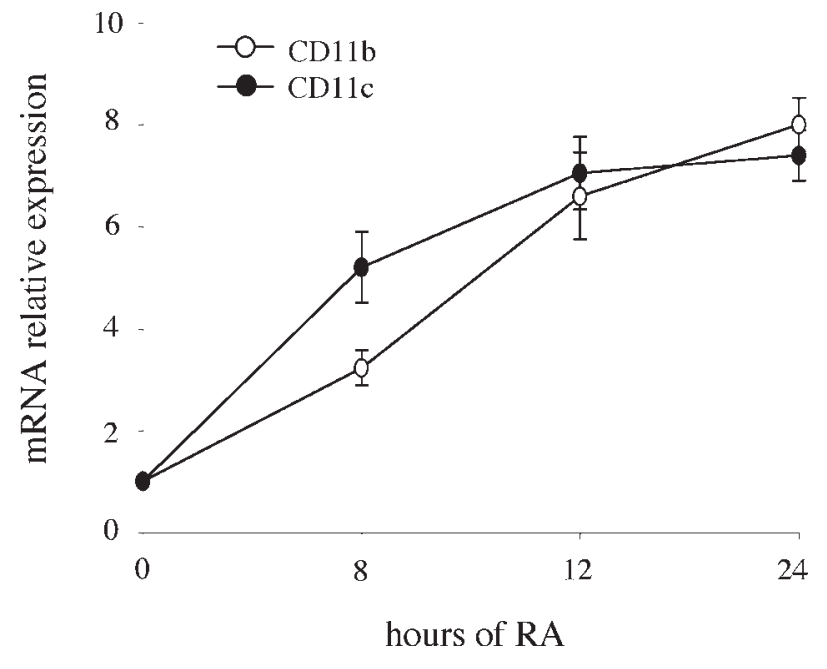

Fig. 1. Real-Time quantitative RT-PCR of RAtreated NB4 cells. Cells were treated with $1 \mu M$ retinoic acid (RA) for 8, 12, and $24 \mathrm{~h}$ and expression of specific surface antigens was valuated by one-step Real-Time quantitative reverse transcriptase polymerase chain reaction (RT-PCR). mRNA relative expression of $\mathrm{CD} 11 \mathrm{~b}(\mathrm{O})$ and $\mathrm{CD} 11 \mathrm{c}(\mathbf{O})$ during RA time-course are shown. Samples were normalized considering glyceraldehyde-3-phosphate dehydrogenase (GAPDH) expression. Values $( \pm$ s.d.) are expressed as fold-induction compared with untreated control $(0 \mathrm{~h})$ and they indicate the mean values of three independent experiments.

cific one. Thus, we controlled the specificity of RT-PCR reaction by agarose gel electrophoresis confirming the presence of a single amplification product (data not shown). The SYBR Green dye was preferred to fluorescent probes (TaqMan) considering the necessity to amplify several differentiation markers and to design the most affordable assay possible. Since the FACS analysis is the procedure most frequently used to follow cellular differentiation, we analyzed the sensitivity of quantitative RT-PCR approach comparing it with that of FACS procedure. To this end, part of the same cellular material used for the described quantitative RT-PCR experiments was processed to monitor the expression of the same surface antigens by FACS analysis. Considering either the percentage of differentiated (positive) cells and the mean fluorescence values of each sample, a detectable increase of both CD11b and
CD11c protein expression could be monitored only after $24 \mathrm{~h}$ of RA induction (Table 3), whereas RT-PCR assay allows to detect CD11b and CD11c mRNA up-regulation at earlier time points (8-12 h, Table 2 and Fig. 1).

\subsection{PML/RAR $\alpha$ Leukemogenic Activity by Real-Time Quantitative RT-PCR}

We also evaluated the feasibility of Real-Time quantitative RT-PCR to study the biological properties of PML/RAR $\alpha$ oncofusion protein, and we considered promonocytic U937 cells as alternative differentiation model system. U937 cells can be efficiently induced to differentiate by treatment with 1,25 dihydroxy $\mathrm{VitD}_{3}$ and $\mathrm{TGF}_{1}(\mathbf{1 4})$. In order to evaluate the timing of differentiation response, U937 cells were treated with $\mathrm{VitD}_{3}(250$ $\mathrm{ng} / \mu \mathrm{L})$ and $\mathrm{TGF} \beta_{1}(1 \mathrm{ng} / \mu \mathrm{L})$ for different lengths of times $(8,12$, and $24 \mathrm{~h})$ and the expression of the CD14, CD11b, and CD11c genes as specific markers of monocyte/macrophage maturation was determined (7). Fifty nanograms of the isolated total RNA were subjected to One-Step quantitative RT-PCR assay for the genes of interest. The specificity of quantitative RT-PCR reaction was monitored by agarose gel (data not shown). The induction of CD14 expression was observed after only $8 \mathrm{~h}$ of $\mathrm{VitD}_{3} / \mathrm{TGF}_{1}(>20$ fold) and it was greatly increased after $24 \mathrm{~h}$ (>100-fold). Results obtained from three independent experiments are summarized in Table $\mathbf{4}$ and Fig. 2. A less strong induction of CD11b expression, if compared with CD14 upregulation, was detected throughout the time-course, while $\mathrm{VitD}_{3} /$ TGF $\beta_{1}$ treatment did not influence CD11c expression (Table 4; Fig. 2).

The PML/RAR $\alpha$ fusion protein blocks the maturation of hematopoietic precursors at the promyelocytic stage of differentiation, leading to formation of leukemic blasts $(7,12)$. Promonocytic U937-PR9 cell line, a subclone of U937 cell line stably transfected with the PML/RAR $\alpha$ cDNA under the control of a Zinc $\left(\mathrm{Zn}^{++}\right)$inducible promoter, was selected as a valid leukemic model system and was used to demonstrate the PML/ RAR $\alpha$-dependent block of $\mathrm{VitD}_{3} / \mathrm{TGF} \beta_{1}$ induced differentiation (7). To test the quantitative RT- 
Table 2

Real-Time Quantitative RT-PCR in RA-Treated NB4 Cells (Three Independent Experiments)

\begin{tabular}{lcccc}
\hline & \multicolumn{4}{c}{ RA time-course } \\
\cline { 2 - 5 } Gene & $0 \mathrm{~h}$ & $8 \mathrm{~h}$ & $12 \mathrm{~h}$ & $24 \mathrm{~h}$ \\
\hline CD11b & $1.00 \pm 0.20$ & $3.34 \pm 0.04$ & $7.07 \pm 0.54$ & $8.22 \pm 1.21$ \\
CD11c & $1.00 \pm 0.05$ & $5.89 \pm 0.28$ & $7.85 \pm 0.57$ & $7.60 \pm 1.50$ \\
CD11b & $1.00 \pm 0.13$ & $2.85 \pm 0.23$ & $5.67 \pm 0.20$ & $7.40 \pm 1.26$ \\
CD11c & $1.00 \pm 0.10$ & $4.50 \pm 0.39$ & $6.50 \pm 0.43$ & $6.80 \pm 1.01$ \\
CD11b & $1.00 \pm 0.18$ & $3.50 \pm 0.25$ & $7.20 \pm 0.26$ & $8.40 \pm 1.23$ \\
CD11c & $1.00 \pm 0.12$ & $5.20 \pm 0.30$ & $6.80 \pm 0.41$ & $7.70 \pm 1.30$ \\
\hline
\end{tabular}

Table 3

FACS Analysis of RA-Treated NB4 Cells

\begin{tabular}{llllll}
\hline \multirow{2}{*}{$\begin{array}{l}\text { RA } \\
\text { treatment }\end{array}$} & \multicolumn{2}{c}{ CD11b } & & \multicolumn{2}{c}{ CD11c } \\
\cline { 2 - 3 } \% pos. cells & mean fluoresc. & & \% pos. cells & mean fluoresc. \\
\hline $0 \mathrm{~h}$ & 0.66 & 14.03 & & 0.54 & 6.41 \\
$8 \mathrm{~h}$ & 0.74 & 15.06 & & 0.68 & 7.17 \\
$12 \mathrm{~h}$ & 1.64 & 19.48 & & 0.9 & 10.68 \\
$24 \mathrm{~h}$ & 15.12 & 41.97 & & 3.12 & 22.4 \\
\hline
\end{tabular}

Table 4

Real-Time Quantitative RT-PCR in VitD $3 /$ TGF $\beta_{1}$-Treated U937-MT and PR9 Cells (Three Independent Experiments)

\begin{tabular}{llrrrr}
\hline & & \multicolumn{4}{c}{ VitD $/ \mathrm{TGF}_{1}$ time-course } \\
\cline { 3 - 6 } Gene & Cell line & \multicolumn{1}{c}{$0 \mathrm{~h}$} & \multicolumn{1}{c}{$8 \mathrm{~h}$} & \multicolumn{1}{c}{$12 \mathrm{~h}$} & \multicolumn{1}{c}{$24 \mathrm{~h}$} \\
\hline CD14 & MT & $1.00 \pm 1.11$ & $25.00 \pm 0.47$ & $76.23 \pm 0.42$ & $141.94 \pm 10.30$ \\
& PR9 & $1.00 \pm 0.26$ & $2.78 \pm 0.09$ & $10.10 \pm 1.90$ & $13.50 \pm 2.62$ \\
CD11b & MT & $1.00 \pm 0.05$ & $3.83 \pm 0.20$ & $12.94 \pm 0.42$ & $25.18 \pm 1.17$ \\
& PR9 & $1.00 \pm 0.14$ & $1.55 \pm 0.14$ & $7.80 \pm 0.61$ & $23.00 \pm 1.27$ \\
CD11c & MT & $1.00 \pm 0.28$ & $1.49 \pm 0.49$ & $0.87 \pm 0.17$ & $1.90 \pm 0.15$ \\
& PR9 & $1.00 \pm 0.12$ & $1.34 \pm 0.10$ & $1.80 \pm 0.53$ & $1.80 \pm 0.18$ \\
CD14 & MT & $1.00 \pm 0.26$ & $37.00 \pm 0.44$ & $97.00 \pm 8.73$ & $155.00 \pm 12.20$ \\
& PR9 & $1.00 \pm 0.40$ & $3.70 \pm 0.56$ & $10.60 \pm 1.09$ & $15.10 \pm 2.00$ \\
CD11b & MT & $1.00 \pm 0.15$ & $3.25 \pm 0.32$ & $10.58 \pm 0.19$ & $28.58 \pm 2.53$ \\
& PR9 & $1.00 \pm 0.16$ & $1.57 \pm 0.08$ & $5.10 \pm 0.44$ & $20.00 \pm 0.96$ \\
CD11c & MT & $1.00 \pm 0.16$ & $1.00 \pm 0.04$ & $1.20 \pm 0.15$ & $1.24 \pm 0.35$ \\
& PR9 & $1.00 \pm 0.32$ & $1.24 \pm 0.43$ & $0.80 \pm 0.13$ & $1.50 \pm 0.42$ \\
CD14 & MT & $1.00 \pm 0.09$ & $22.00 \pm 0.26$ & $80.00 \pm 1.32$ & $130.00 \pm 19.70$ \\
& PR9 & $1.00 \pm 0.09$ & $3.13 \pm 0.13$ & $9.52 \pm 1.33$ & $16.30 \pm 4.40$ \\
CD11b & MT & $1.00 \pm 0.08$ & $3.10 \pm 0.51$ & $10.20 \pm 1.20$ & $23.50 \pm 2.30$ \\
& PR9 & $1.00 \pm 0.17$ & $2.10 \pm 0.13$ & $7.90 \pm 0.32$ & $22.40 \pm 1.31$ \\
CD11c & MT & $1.00 \pm 0.19$ & $1.50 \pm 0.08$ & $1.20 \pm 0.10$ & $1.00 \pm 0.20$ \\
& PR9 & $1.00 \pm 0.08$ & $1.25 \pm 0.17$ & $1.53 \pm 0.58$ & $1.42 \pm 0.60$ \\
\hline
\end{tabular}




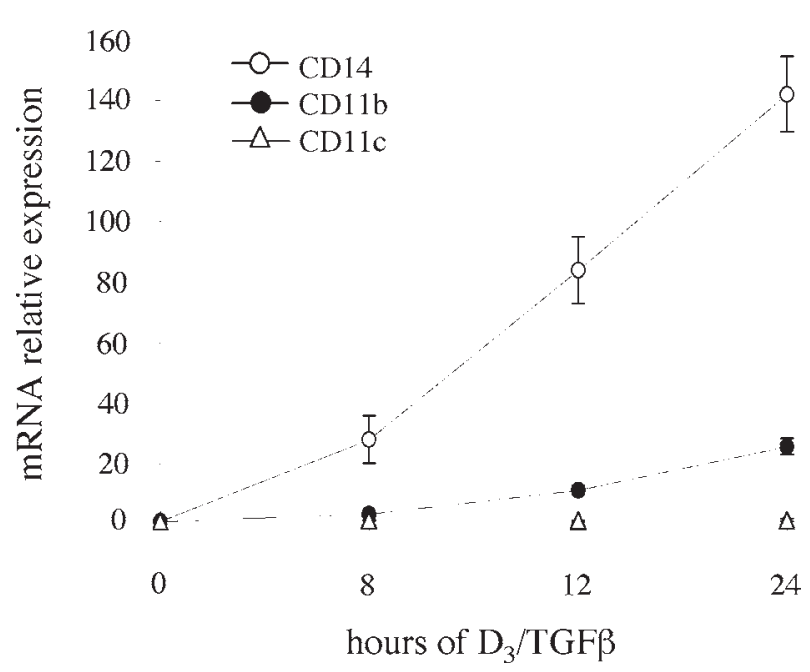

Fig. 2. Real-Time quantitative RT-PCR of $\mathrm{VitD}_{3} /$ TGF $\beta_{1}$-treated U937 cells. Cells were treated with 250 $\mathrm{ng} / \mathrm{mL}$ of $\mathrm{VitD}{ }_{3}$ and $1 \mathrm{ng} / \mathrm{mL}$ of TGF $\beta_{1}$ for 8,12 , and $24 \mathrm{~h}$ and expression of specific surface antigens was valuated by one-step Real-Time quantitative reverse transcriptase polymerase chain reaction (RT-PCR). mRNA relative expression of CD14 (O), CD11b (O), and $\mathrm{CD} 11 \mathrm{c}(\triangle)$ during $\mathrm{VitD}_{3} / \mathrm{TGF}_{1}$ time-course are shown. Samples were normalized considering glyceraldehyde-3-phosphate dehydrogenase (GAPDH) expression. Values ( \pm s.d.) are expressed as fold-induction compared with untreated control $(0 \mathrm{~h})$ and they indicate the mean values of three independent experiments.

PCR assay as method for differentiation studies we treated U937-PR9 cells with $100 \mu M \mathrm{ZnSO}_{4}$ for $12 \mathrm{~h}$ to induce PML/RAR $\alpha$ expression and then we added $250 \mathrm{ng} / \mathrm{mL} \mathrm{VitD}_{3}$ and $1 \mathrm{ng} / \mathrm{mL}$ TGF $\beta_{1}$ for different lengths of times $(8,12$, and $24 \mathrm{~h}$ ) to induce the differentiation response. We monitored the expression of CD14, CD11b, and CD11c mRNA in the U937-PR9 clone (and U937Mt as control) by quantitative RT-PCR (Table 4). We could observe a great reduction in the CD14 mRNA levels due to the expression of PML/ RAR $\alpha$ protein (Fig. 3A). As reported also by Grignani et al. (7), CD11b expression was modulated by $\mathrm{VitD}_{3} / \mathrm{TGF}_{1}$ treatment but its expression was not drastically influenced by PML/RAR $\alpha$ fusion protein (Fig. 3B), while CD11c showed a constant expression profile during the time-course (Fig. 3C).
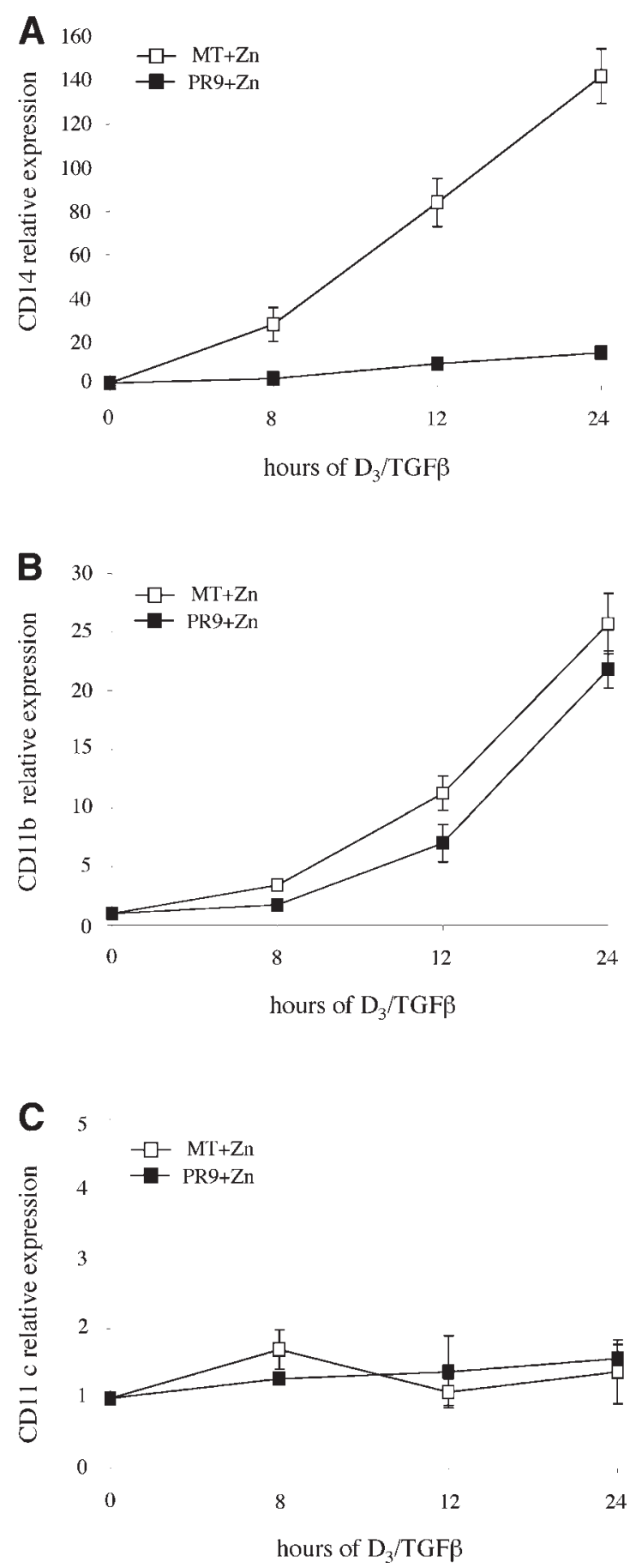

Fig. 3. PMLRAR $\alpha$-induced block of differentiation by quantitative RT-PCR. CD14 (A), CD11b (B), and CD11c (C) expression in $\mathrm{VitD}_{3} / \mathrm{TGF}_{1}$ treated U937MT not expressing ( $\square$ ) or U937-PR9 expressing (ם) PMLRAR $\alpha$ protein. Cells were previously induced with $100 \mathrm{mM}$ of $\mathrm{ZnSO}_{4}$ for $12 \mathrm{~h}(\mathrm{MT}+\mathrm{Zn}$ or PR9+Zn). Values are shown as fold-induction compared with untreated control $(0 \mathrm{~h})$. 
Table 5

FACS Analysis of VitD TGF $_{1}$-Treated U937 Cells Expressing (PR9) or Not (MT) PML/RAR $\alpha$ Protein

\begin{tabular}{lcc} 
A. U937-MT & \multicolumn{2}{c}{ CD14 expression } \\
\cline { 2 - 3 } D $_{3}$ TGF $\beta$ treatment & \% posit. cells & mean fluoresc. \\
\hline $0 \mathrm{~h}$ & 0.62 & 8.73 \\
$8 \mathrm{~h}$ & 12.81 & 13.81 \\
$12 \mathrm{~h}$ & 46.59 & 136.22 \\
$24 \mathrm{~h}$ & 94.44 & 797.15
\end{tabular}

B. U937-PR9

\begin{tabular}{ccc} 
& \multicolumn{2}{c}{ CD14 expression } \\
\cline { 2 - 3 } $\mathrm{D}_{3} / \mathrm{TGF} \beta$ treatment & \% posit. cells & mean fluoresc. \\
\hline $0 \mathrm{~h}$ & 0.42 & 13.46 \\
$8 \mathrm{~h}$ & 0.68 & 12.63 \\
$12 \mathrm{~h}$ & 8.99 & 36.80 \\
$24 \mathrm{~h}$ & 18.16 & 196.72 \\
\hline
\end{tabular}

We then compared the sensitivity and the reproducibility of the quantitative RT-PCR assay with the flow-cytofluorimetric approach. Part of the same cellular material, used to perform quantitative RT-PCR assay, has been stained with a monoclonal anti-CD14 antibody to detect the CD14 protein expression by FACS analysis. As reported in Table 4, the RT-PCR assay allowed us to detect a reproducible differentiation cellular response after only $8 \mathrm{~h}$ of $\mathrm{VitD}_{3} / \mathrm{TGF} \beta_{1}$ induction as compared with that observed at $24 \mathrm{~h}$ by flowcytofluorimetric assay (Table 5).

Our results demonstrate the possibility to follow the cellular maturation using the Real-Time quantitative RT-PCR assay. Although the canonical FACS analysis has still to be considered the most powerful technique to study cellular differentiation, we shown the feasibility to detect a more precocious maturation response by quantitative RT-PCR.

RA-resistance is one of the most studied phenomenon occurring after prolonged RA treatment of PML/RAR $\alpha$ expressing blasts or characterizing APL blasts expressing PLZF/RAR $\alpha$ protein $(<5 \%$ of total APL cases) $(9,15)$. The higher sensitivity of RT-PCR assay could be useful in those experimental conditions in which it is necessary to evaluate a limited maturation response of RAresistant cells, otherwise undetectable by using the canonical FACS analysis (e.g., monitoring the cellular response induced by antisense approaches directed to abrogate the expression of either PLZF/RAR $\alpha$ or the mutated RA-resistant version of PML/RAR $\alpha$ ). Moreover, the quantitative RTPCR approach could be considered in preliminar screening of new compounds with potential differentiative activity. In these cases it could be necessary to treat the cellular population for short periods of time to avoid possible cellular toxicity, and it could be experimentally crucial to use the most sensitive approach to detect a maturative response.

In our opinion, the real-time PCR assay could be considered not really an alternative assay to FACS analysis but an experimental tool useful in the experimental conditions leading to differentiating cellular response difficult to detect.

\section{Acknowledgments}

We thank Angela Santoni, Mauro Magnani, and Luca Galluzzi for their helpful discussion. This work is supported by the Fanoateneo donation.

\section{References}

1. Alcalay, M., Zangrilli, D., Pandolfi, P. P., et al. (1991) Translocation breakpoint of acute promyelocytic leukemia lies within the retinoic acid receptor alpha locus. Proc. Natl. Acad. Sci. USA 88, 1977-1981.

2. Goddard, A., Borrow, J., Freemont, P., and Solomon, E. (1991) Characterization of a zinc finger gene disrupted by the $\mathrm{t}(15 ; 17)$ in acute promyelocytic leukemia. Science 254, 1371-1374.

3. Kakizuka, A., Miller, W. J., Umesono, K., et al. (1991) Chromosomal translocation $\mathrm{t}(15 ; 17)$ in human acute promyelocytic leukemia fuses RAR alpha with a novel putative transcription factor PML. Cell 66, 663-674.

4. Warrel, R. P. Jr., de The, H., Wang, Z.Y., and Degos, L. (1993) Acute promyelocytic leukemia. N. Engl. J. Med. 329, 177-189.

5. Grignani, F., Fagioli, M., Alcalay, M., et al. (1994) Acute promyelocytic leukemia: From genetics to treatment. Blood 83, 10-25.

6. Chomienne, C., Fenaux, P., and Degos, L. (1996) Retinoid differentiation therapy in promyelocytic leukemia. FASEB J. 10, 1025-1030.

7. Grignani, F. R., Ferrucci, P. F., Testa, U., et al. (1993) The acute promyelocytic leukemia-specific PML/ RAR $\alpha$ fusion protein inhibits differentiation and pro- 
motes survival of myeloid precursor cells. Cell 74, 423-431.

8. Nervi, C., Ferrara, F. F., Fanelli, M., et al. (1998) Caspases mediate retinoic acid-induced degradation of the acute promyelocytic leukemia PML/RAR $\alpha$ fusion protein. Blood $\mathbf{9 2}$, 2244-2251.

9. Fanelli, M., Minucci, S., Gelmetti, V., Nervi, C., Gambacorti-Passerini, C., and Pelicci, P. G. (1999) Constitutive degradation of PML/RAR $\alpha$ through the proteasome pathway mediates retinoic acid resistance. Blood 93, 1477-1481.

10. Higuchi, R., Dollinger, G., Walsh, P.S., and Griffith, R. (1992) Simultaneous amplification and detection of specific DNA sequences. Biotechnology (NY) 10, 413-417.

11. Lanotte, M., Martin-Thouvenin, V., Najman, S., Ballerini, P., Valensi, F., and Berger, R. (1991) NB4, a maturation inducible cell line with $\mathrm{t}(15 ; 17)$ marker isolated from a human acute promyelocytic leukemia (M3). Blood 77, 1080-1086.

12. Grignani, F., Testa, U., Rogaia, D., et al. (1996) Effects on differentiation by the promyelocytic leukemia PML/RAR $\alpha$ protein depend on the fusion of PML protein dimerization and RAR $\alpha$ DNA binding domains. Embo J. 15, 4949-4958.

13. Livak, K. J. and Schmittgen, T. D. (2001) Analysis of relative gene expression data using Real-Time quantitative PCR and 2(-Delta DeltaC(T)) method. Methods 25, 402-408.

14. Testa, U., Masciulli, R., Tritarelli, E., et al. (1993) Transforming growth factor-beta potentiates vitamin D3-induced terminal monocytic differentiation of human leukemic cell lines. J. I mm unol. 150, 2418-2430.

15. Grignani, F., De Matteis, S., Nervi, C., et al. (1998) Fusion proteins of the retinoic acid receptor-a recruit histone deacetylase in promyelocytic leukaemia. $\mathrm{Na}$ ture 391, 815-818. 